\title{
Analisis Faktor yang Berhubungan dengan Pelaksanaan Manajemen Nyeri Non Farmakologis Oleh Perawat Pelaksana di Irna Non Bedah RSUP Dr M Djamil Padang Tahun 2015
}

\author{
Fitria Fajriani*, Yulastri Arif, Deswita \\ Program Studi Magister Keperawatan Universitas Andalas Padang \\ *Correspondence emai: fitriafajriani@gmail.com
}

\begin{abstract}
Abstrak. Angka kenyamanan pasien atau pasien bebas dari nyeri merupakan salah satu indikator mutu pelayanan kesehatan di ruang rawat inap. Salah satu upaya perawat untuk meningkatkan angka mutu tersebut adalah manajemen nyeri nonfarmakologis. Irna non bedah memiliki angka nyeri yang cukup tinggi, namun angka tatalaksana nyeri yang dilakukan oleh perawat masih rendah. Tujuan penelitian ini adalah untuk menganalisis faktor yang berhubungan dengan pelaksanaan manajemen nyeri nonfarmakologis oleh perawat pelaksana di Irna Non Bedah. Penelitian ini menggunakan desain analitik dengan pendekatan Cross Sectional. Sampel penelitian ini sebanyak 89 orang yang diambil secara purposive. Instrumen penelitin ini dibuat oleh peneliti yang telah dilakukan uji validitas dan reliabilitas. Hasil penelitian menunjukkan lebih dari separuh $(59,6 \%)$ perawat pelaksana kurang baik dalam melaksanakan manajemen nyeri nonfarmakologis. Berdasarkan uji statistic Chi-square, terdapat hubungan yang bermakna antara pelatihan, pengetahuan, sikap dan motivasi terhadap pelaksanaan manajemen nyeri nonfarmakologis dengan masing-masing Pvalue $(0,001 ; 0,007 ; 0,001 ; 0,001)$. Faktor yang memiliki kontribusi paling besar terhadap pelaksanaan manajemen nyeri nonfarmakologis adalah pelatihan. Oleh sebab itu diharapkan kepada institusi pelayanan untuk dapat membuat program pelatihan yang berkelanjutan tentang manajemen nyeri nonfarmakologis.
\end{abstract}

Kata Kunci : Manajemen nyeri nonfarmakologis; pelaksanaan; perawat

\begin{abstract}
The comfort rate of patients or patients free from pain is one indicator of the quality of health services in inpatient rooms. One of the nurse's efforts to improve the quality rate is non-pharmacological pain management. Non-surgical Irna has a fairly high pain rate, but the number of pain management performed by nurses is still low. The purpose of this study was to analyze the factors associated with the implementation of non-pharmacological pain management by nurses at Irna Non-Surgical. This study uses an analytical design with a Cross Sectional approach. The sample of this study was 89 people who were taken purposively. This research instrument was made by researchers who have been tested for validity and reliability. The results showed that more than half (59.6\%) of nurses were not good at implementing non-pharmacological pain management. Based on the Chi-square statistical test, there is a significant relationship between training, knowledge, attitudes and motivation towards the implementation of non-pharmacological pain management with each P-value (0.001; 0.007; 0.001; 0.001). The factor that has the greatest contribution to the implementation of non-pharmacological pain management is training. Therefore, it is expected that service institutions can create sustainable training programs on non-pharmacological pain management.
\end{abstract}

Keywords: Non-pharmacological pain management; implementation; nurses

\section{PENDAHULUAN}

Nyeri merupakan alasan utama seseorang mencari pelayanan kesehatan. Menurut Potter dan Perry (2005) nyeri dapat didefinisikan sebagai suatu sensasi yang bersifat lokal dan dapat berkisar dari ringan sampai berat. Selain itu International Association for Study of Pain IASP (1979, dalam White, 2001), juga mendefinisikan nyeri sebagai sensori subjektif dan emosional yang tidak menyenangkan yang dapat terkait dengan kerusakan jaringan aktual maupun potensial, atau menggambarkan kondisi terjadinya suatu kerusakan.

Manajemen nyeri merupakan indikator mutu pelayanan keperawatan. Perserikatan Bangsa Bangsa (1948 dalam Chuandy, 2015) mendeklarasikan bahwa penanganan nyeri merupakan salah satu hak asasi manusia. Demikian pentingnya penanganan nyeri menjadikan nyeri sebagai vital sign yang kelima, setelah nafas, tekanan darah, nadi dan suhu, sehingga manajemen nyeri mutlak harus ada (Casey, 2011).
Manajemen nyeri terdiri dari manajemen nyeri Farmakologis dan Manajemen nyeri non-farmakologis. Manajemen nyeri non-farmakologis merupakan intervensi keperawatan secara mandiri, sedangkan manajemen nyeri farmakologis adalah tindakan kolaboratif bagi perawat. Manajemen nyeri non farmakologis dapat digunakan sebagai terapi tunggal kepada pasien dengan nyeri ringan. Selain itu, manajemen nyeri non farmakologis juga menjadi terapi pelengkap dalam mengurangi dan mengontrol nyeri pasien untuk nyeri sedang dan berat. Manajemen nyeri non farmakologis dapat memperkuat kerja analgetik dan mempersingkat durasi nyeri pasien.

Manajemen nyeri non farmakologi, merupakan tindakan mandiri perawat untuk menghilangkan nyeri dengan menggunakan teknik manajemen nyeri, misalnya dengan teknik biofeedback, Transcutan Electric Nervous Stimulating ( TENS ), relaksasi, guided imagery, terapi musik, distraksi, terapi bermain, acupressure, aplikasi 
Fitria Fajriani et al., Analisis Faktor yang Berhubungan dengan Pelaksanaan Manajemen Nyeri Non Farmakologis Oleh Perawat Pelaksana di Irna Non Bedah RSUP Dr M Djamil Padang Tahun 2015

panas/ dingin, massage, dan hipnosis (Potter dan Perry, 2005). Penatalaksanaan nyeri non-farmakologis ini diberikan berdasarakan teori gate control dari Melzack dan Wall (1965) dalam Smeltzer \& Bare (2002)

\section{METODE}

Penelitian ini adalah penelitian kuantitatif desain Analitik dengan pendekatan Cross Sectional (Notoatmodjo, 2012). Sampel Penelitian ini adalah 89 orang perawat pelaksana di Irna Non Bedah RSUP M Djamil Padang.

\section{HASIL DAN PEMBAHASAN}

Pelaksanaan Manajemen Nyeri Non Farmakologis Oleh Perawat Pelaksana Di Instalasi Rawat Inap Non Bedah RSUP Dr M Djamil Padang Tahun 2015

Tabel 1. Distribusi Frekuensi Pelaksanaan Manajemen Nyeri Nonfarmakologis Oleh Perawat Pelaksana Di Instalasi Rawat Inap Non Bedah Rsup Dr M Djamil Padang Tahun 2015

\begin{tabular}{lcc}
\hline $\begin{array}{c}\text { Pelaksanaan Manajemen nyeri } \\
\text { nonfarmakologis }\end{array}$ & F & $\%$ \\
\hline Baik & 36 & 40,4 \\
Kurang Baik & 53 & 59,6 \\
\hline
\end{tabular}

Tabel 1 memperlihatkan lebih dari separuh $(59,6 \%)$ perawat pelaksana di Irna non bedah kurang baik dalam melaksanakan manajemen nyeri nonfarmakologis.

Faktor Predisposisi Pelaksanaan Manajemen Nyeri Nonfarmakologis Oleh Perawat Pelaksana Di Instalasi Rawat Inap Non Bedah RSUP Dr M Djamil Padang Tahun 2015

Faktor predisposisi pelaksanaan manajemen nyeri nonfarmakologis dianalisis dengan proporsi dan disajikan dalam bentuk tabel distribusi. Setelah dilakukan uji normalitas didapatkan bahwa data variabel pengetahuan, sikap, motivasi dan supervisi tidak terdistribusi normal. Lebih rinci dapat dilihat dalam tabel 2:

Tabel 2. Distribusi Frekuensi Faktor Presdisposisi Pelaksanaan Manajemen Nyeri Nonfarmakologis Oleh Perawat Pelaksana Di Instalasi Rawa Inap Non Bedah RSUP Dr M Djamil Padang Tahun 2015 ( $\mathrm{n}=89$ )

\begin{tabular}{|c|c|c|c|c|}
\hline No & Variabel & Kategori & f & $\%$ \\
\hline \multirow[t]{9}{*}{1} & Karakteristik & & & \\
\hline & a. Usia & - Dewasa awal & 87 & 97,8 \\
\hline & & - Dewasa madya & 2 & 2,2 \\
\hline & b. Pendidikan & - D3Keperawatan & 86 & 96,6 \\
\hline & & - S1 Keperawatan & 3 & 3,4 \\
\hline & c. Masa Kerja & - $<5$ Tahun & 28 & 31,5 \\
\hline & & $\cdot \geq 5$ Tahun & 61 & 68,5 \\
\hline & d. Pelatihan & - Tidak Pernah & 71 & 79,8 \\
\hline & manajemen nyeri & - Pernah & 18 & 20,2 \\
\hline \multirow[t]{2}{*}{2} & Pengetahuan & - Baik & 61 & 68,5 \\
\hline & & - Kurang & 28 & 31,5 \\
\hline \multirow[t]{2}{*}{3} & Sikap & - Positif & 37 & 41,6 \\
\hline & & - Negatif & 52 & 58,4 \\
\hline \multirow[t]{2}{*}{4} & Motivasi & - Tinggi & 33 & 37,1 \\
\hline & & - Rendah & 56 & 62,9 \\
\hline
\end{tabular}

Tabel 2 memperlihatkan hampir seluruh perawat pelaksana di Irna non bedah berada pada usia dewasa awal $(97,8 \%)$, dengan pendidikan Diploma III $(96,6 \%)$. Sedangkan lebih dari separuh $(68,5 \%)$ perawat pelaksana memiliki masa kerja > 5 tahun. Namun sebagian besar $(79,8 \%)$ perawat pelaksana belum mengikuti pelatihan manajemen nyeri. Lebih dari separuh $(68,5 \%)$ perawat pelaksana di Irna non bedah memiliki pengetahuan yang baik tentang manajemen nyeri nonfarmakologis. Namun lebih dari separuh $(58,4 \%)$ perawat pelaksana memiliki sikap negatif dan motivasi rendah tentang manajemen nyeri nonfarmakologis $(62,9 \%)$.

Faktor Pendorong Pelaksanaan Manajemen Nyeri Non Farmakologis Oleh Perawat Pelaksana Di Instalasi Rawat Inap Non Bedah RSUP Dr M Djamil Padang Tahun 2015

Faktor pendorong yaitu supervisi pelaksanaan manajemen nyeri non farmakologis oleh perawat pelaksana di Irna non bedah RSUP Dr M Djamil Padang, dalam bentuk kategorik sehingga dianalisis dengan proporsi dan disajikan dengan tabel distribusi frekuensi. Secara rinci dapat dilihat dalam tabel 3

Tabel 3. Distribusi Frekuensi Faktor Pendorong Pelaksanaan Manajemen Nyeri Nonfarmakologis Oleh Perawat Pelaksana Di Instalasi Rawa Inap Non Bedah RSUP Dr M Djamil Padang Tahun

\begin{tabular}{llll}
\multicolumn{4}{c}{$2015(\mathrm{n}=89)$} \\
\hline Variabel & \multicolumn{1}{c}{ Kategori } & f & \% \\
\hline Supervisi & - Baik & 43 & 48,3 \\
& - Kurang baik & 46 & 51,7 \\
\hline
\end{tabular}

Tabel 3 memperlihatkan lebih dari separuh $(51,7 \%)$ perawat pelaksana memiliki persepsi kurang baik tentang supervisi kepala ruangan terhadap manajemen nyeri nonfarmakologis.

Hubungan Faktor Predisposisi (Karakteristik, Pengetahuan, Sikap, Motivasi) dengan pelaksanaan manajemen nyeri nonfarmakologis oleh perawat pelaksana di Irna non bedah RSUP Dr M Djamil Padang tahun 2015

Tabel 4. Hubungan Faktor Predisposisi Dengan Pelaksanaan Manajemen Nyeri Nonfarmakologis Oleh Perawat Pelaksana Di Irna Non Bedah RSUP Dr M Djamil Padang tahun 2015

\begin{tabular}{|c|c|c|c|c|c|c|c|}
\hline \multirow{3}{*}{ Faktor Predisposisi } & \multicolumn{4}{|c|}{$\begin{array}{c}\text { Pelaksanaan } \\
\text { manajemen nyeri }\end{array}$} & \multirow{3}{*}{ Total } & \multirow{3}{*}{$\%$} & \multirow{3}{*}{$P$ Value } \\
\hline & \multicolumn{2}{|c|}{ Baik } & \multirow{2}{*}{\multicolumn{2}{|c|}{$\begin{array}{c}\text { Kurang } \\
\text { Baik }\end{array}$}} & & & \\
\hline & $\mathbf{f}$ & $\%$ & $\mathbf{f}$ & & & & \\
\hline \multirow{2}{*}{\multicolumn{8}{|c|}{ Karakteristik }} \\
\hline & & & & & & & \\
\hline - Dewasa Awa1 & 35 & 40,2 & 52 & 59,8 & 87 & 100 & \multirow{2}{*}{1,000} \\
\hline - Dewasa madya & 1 & 50 & 1 & 50 & 2 & 100 & \\
\hline \multicolumn{8}{|l|}{ Pendidikan } \\
\hline - D3 Keperawatan & 35 & 40,7 & 51 & 59,3 & 86 & 100 & \multirow[t]{3}{*}{1,000} \\
\hline \multirow{3}{*}{\multicolumn{7}{|c|}{ Masa kerja }} & \\
\hline & & & & & & & \\
\hline & & & 15 & 53,6 & 28 & 100 & \multirow[t]{3}{*}{0,585} \\
\hline$-\geq 5$ tahun & 23 & 37,7 & 38 & 62,3 & 61 & 100 & \\
\hline \multicolumn{7}{|l|}{ Pelatihan Manajemen nyeri } & \\
\hline - Tidak Pernah & 22 & 31 & 49 & 69 & 71 & 100 & \multirow[t]{3}{*}{0,001} \\
\hline - Pernah & 14 & 83,3 & 4 & 16,7 & 18 & 100 & \\
\hline \multicolumn{7}{|l|}{ Pengetahuan } & \\
\hline - Baik & 31 & 50,8 & 30 & 49,2 & 61 & 100 & \multirow[t]{2}{*}{0,007} \\
\hline \multirow{2}{*}{\multicolumn{8}{|c|}{ Sikap }} \\
\hline & & & & & & & \\
\hline -Positif & 23 & 62,2 & 14 & 37,8 & 37 & 100 & \multirow[t]{2}{*}{0,001} \\
\hline - Negatif & 13 & 25 & 39 & 75 & 52 & 100 & \\
\hline \multicolumn{8}{|l|}{ Motivasi } \\
\hline - Tinggi & 21 & 63,6 & 12 & 36,4 & 33 & 100 & \multirow[t]{2}{*}{0,001} \\
\hline - Rendah & 15 & 26,8 & 41 & 73,2 & 56 & 100 & \\
\hline
\end{tabular}


Fitria Fajriani et al., Analisis Faktor yang Berhubungan dengan Pelaksanaan Manajemen Nyeri Non Farmakologis Oleh Perawat Pelaksana di Irna Non Bedah RSUP Dr M Djamil Padang Tahun 2015

*bermakna pada $\alpha<0,05$

Tabel 4 memperlihatkan bahwa karakteristik perawat pelaksana di Instalasi rawat inap Non bedah RSUP M Djamil Padang yang berhubungan dengan pelaksanaan manajemen nyeri nonfarmakologis secara signifikan adalah pelatihan manajemen nyeri $($ Pvalue $=$ 0,001 ). Selain itu faktor predisposisi yang memiliki hubungan yang bermakna dengan pelaksanaan manajemen nyeri nonfarmakologis oleh perawat pelaksana di Irna non bedah RSUP Dr M Djamil Padang adalah pengetahuan $($ Pvalue $=0,007)$, sikap (Pvalue $=$ $0,001)$ dan motivasi $($ Pvalue $=0,001)$.

Hubungan Faktor Pendorong (Supervisi) dengan pelaksanaan manajemen nyeri nonfarmakologis oleh perawat pelaksana di Irna non bedah RSUP Dr M Djamil Padang tahun 2015

Faktor pendorong adalah persepsi perawat pelaksana terhadap supervisi Karu tentang manajemen nyeri nonfarmakologis. Penjelasan lebih rinci dapat dilihat dalam tabel 5

Tabel 5. Hubungan Faktor Pendorong (Supervisi) Dengan

Pelaksanaan Manajemen Nyeri Nonfarmakologis Oleh

Perawat Pelaksana Di Irna Non Bedah RSUP Dr M Djamil Padang tahun 2015

\begin{tabular}{|c|c|c|c|c|c|c|c|}
\hline \multirow{3}{*}{ Faktor Pendorong } & \multicolumn{4}{|c|}{$\begin{array}{c}\text { Pelaksanaan manajemen } \\
\text { nyeri }\end{array}$} & \multirow{3}{*}{ Total } & \multirow{3}{*}{$\%$} & \multirow{3}{*}{$P$ Value } \\
\hline & \multicolumn{2}{|c|}{ Baik } & \multicolumn{2}{|c|}{ Kurang Baik } & & & \\
\hline & f & $\%$ & f & $\%$ & & & \\
\hline \multicolumn{8}{|l|}{ Supervisi } \\
\hline - Baik & 18 & 41,9 & 25 & 58,1 & 43 & 100 & 0,963 \\
\hline - Kurang baik & 18 & 39,1 & 28 & 60,9 & 46 & 100 & \\
\hline
\end{tabular}

Tabel 5 memperlihatkan bahwa faktor pendorong yaitu supervisi kepala ruangan tentang manajemen nyeri tidak memiliki hubungan yang bermakna dengan pelaksanaan manajemen nyeri nonfarmakologis oleh perawat pelaksana di Instalasi rawat inap Non bedah RSUP M Djamil $($ Pvalue $=0,963)$

\section{Analisis Faktor Yang Paling Berhubungan Dengan pelaksanaan manajemen nyeri non farmakologis.}

Tabel 6. Hasil analisis multivariat regresi logistik antara pelatihan, pengetahuan, dengan pelaksanaan manajemen nyeri nonfarmakologis oleh perawat pelaksana di RSUP Dr M Djamil Tahun 2015

\begin{tabular}{llll}
\hline No & Variabel & B & P value \\
\hline 1 & Pelatihan & 0,341 & 0,005 \\
2 & Pengetahuan & 0,249 & 0,014 \\
3 & Motivasi & 0,269 & 0,007 \\
\hline
\end{tabular}

Berdasarkan tabel diatas diketahui bahwa variabel yang paling dominan berhubungan dengan pelaksanaan manajemen nyeri nonfarmakologis adalah pelatihan manajemen nyeri yang didapatkan oleh perawat pelaksana di Irna Non Bedah RSUP Dr M Djamil Padang tahun 2015 dengan nilai $\mathrm{p}=0,005$.

\section{Pembahasan \\ Pelaksanaan manajemen nyeri non farmakologis oleh perawat pelaksana di Irna Non Bedah RSUP Dr M Djamil Padang tahun 2015}

Hasil penelitian menunjukkan lebih dari separuh $(59,6 \%)$ perawat pelaksana di Irna Non Bedah baik dalam melaksanakan manajemen nyeri non farmakologis. Hasil ini sesuai dengan penelitian yang dilakukan oleh Kursyati \& Astuti (2012) yang menyatakan bahwa lebih dari separuh perawat $(51,5 \%)$ tidak melaksanakan manajemen nyeri nonfarmakologis.

Menurut Bobak (2004) Manajemen nyeri nonfarmakologis bukan sebagai pengganti obat. Kombinasi manajemen nyeri nonfarmakologis dengan manajemen nyeri farmakologis dapat digunakan untuk mengontrol nyeri agar sensasi nyeri dapat berkurang serta masa pemulihan tidak memanjang. Menurut buku panduan akreditasi RSUP Dr M Djamil Padang, Manajemen nyeri nonfarmakologis diberikan secara tunggal kepada pasien dengan skala nyeri ringan. Untuk skala nyeri sedang hingga berat manajemen nyeri nonfarmakologis diberikan secara kombinasi dengan manajemen nyeri farmakologis.

Berdasarkan analisis kuesioner manajemen nyeri nonfarmakologis, lebih dari separuh $(65,1 \%)$ perawat pelaksana hanya melakukan skrining nyeri saat pasien baru masuk. Hal ini bertentangan dengan pernyataan Morone \& Weiner (2013) bahwa skrining nyeri merupakan tanda-tanda vital kelima yang harus diskrining setiap shift atau saat klien mengeluh nyeri.

Hampir seluruh $(96,6 \%)$ perawat pelaksana melakukan pengkajian kepada pasien yang mengeluh nyeri. Namun, pengkajian yang dilakukan oleh perawat tersebut belum sesuai dengan teori pengkajian nyeri. Dapat dilihat bahwa lebih dari separuh perawat $(66,6 \%)$ tidak mengkaji waktu dan periode nyeri pasien, kurang dari separuh $(25,8 \%)$ perawat pelaksana tidak mengkaji skala nyeri pasien, dan kurang dari separuh $(33,7 \%)$ perawat pelaksana tidak mengkaji gambaran rasa nyeri pasien.

Menurut Buyukyilmaz (2014) menyatakan bahwa tekhnik relaksasi, distraksi dan masase dapat menurunkan intensitas nyeri pasien. Maka dapat disimpulkan pelaksanaan manajemen nyeri di Irna Non Bedah RSUP M Djamil masih terbatas pada pengkajian saat pasien masuk, manajemen nyeri farmakologis dan manajemen nyeri nonfarmakologis berupa relaksasi nafas dalam. Menurut peneliti perawat pelaksana di Irna Non Bedah belum memahami pengkajian nyeri dan manajemen nyeri nonfarmakologis secara komprehensif saat memberikan intervensi pada pasien nyeri. 
Faktor Predisposisi Pelaksanaan Manajemen Nyeri Nonfarmakologis Oleh Perawat Pelaksana Di Irna Non Bedah RSUP Dr M Djamil Padang Tahun 2015

1. Karakteristik Perawat Pelaksana Di Instalasi Rawat Inap Non Bedah RSUP Dr M Djamil Padang Tahun 2015

\section{a. Usia Perawat Pelaksana}

Hasil penelitian menunjukkan bahwa perawat pelaksana yang bertugas di Irna Non Bedah RSUP Dr M Djamil Padang hampir seluruh $(97,8 \%)$ perawat pelaksana berada dalam tahap usia dewasa awal. Hasil ini sesuai dengan penelitian yang dilakukan oleh Abdalrahim et al (2011), menyatakan bahwa lebih dari separuh perawat pelaksana $(60 \%)$ berada dalam rentang usia dewasa awal. Hal ini diperkuat oleh hasil penelitian Zhang (2008) yang menyatakan bahwa hampir seluruh $(93,9 \%)$ perawat pelaksana berada dalam rentang usia dewasa awal. Usia dewasa awal merupakan usia yang produktif dan selalu penuh dengan ide-ide dalam bekerja, namun usia dewasa awal belum memiliki banyak pengalaman dalam melaksanakan tugasnya.

Usia berkaitan dengan tingkat kedewasaan dan maturitas seseorang Menurut analisis peneliti faktor usia dapat mempengaruhi pola pikir dan kondisi emosional perawat, namun peningkatan usia dapat menyebabkan penurunan kinerja perawat. Hal ini dapat dipengaruhi oleh penurunan fisiologis tubuh perawat tersebut.

b. Pendidikan Perawat Pelaksana

Hasil penelitian ini menunjukkan bahwa hampir seluruh $(96,6 \%)$ perawat memiliki tingkat pendidikan diploma III keperawatan. Hasil ini sesuai dengan hasil penelitian Juwita (2014) menyatakan bahwa sebagian besar perawat $(89,7 \%)$ perawat pelaksana memiliki latar belakang pendidikan D3 Keperawatan. Hasil ini berbeda dengan penelitian Nugroho (2004) yang menyatakan bahwa lebih dari separuh perawat memiliki pendidikan rendah (SPK). Namun hasil penelitian ini bertentangan dengan penelitian Elrahman et al (2013) yang menyatakan bahwa lebih dari separuh perawat praktisi $(53,7 \%)$ memiliki latar belakang ners (Sarjana Keperawatan). Siagian (2002) menyatakan bahwa pendidikan formal menyangkut kemampuan intelektual yang berkaitan dengan kemampuan individu menyelesaikan tugas dalam pekerjaannya.

Latar belakang pendidikan seseorang akan mempengaruhi produktivitas dan kinerja orang tersebut. Salah satu upaya untuk meningkatkan kinerja perawat adalah dengan meningkatkan sumber daya keperawatan melalui pendidikan ke jenjang yang lebih tinggi. c. Masa Kerja Perawat

Hasil penelitian ini menunjukkan bahwa lebih dari separuh perawat pelaksana $(68,5 \%)$ memiliki masa kerja lebih dari 5 tahun. Hal ini sesuai dengan hasil penelitian Abdalrahim (2011) bahwa lebih dari separuh $(69,09 \%)$ perawat praktisi memiliki masa kerja lebih dari 5 tahun.

Masa kerja adalah lamanya seseorang bekerja pada suatu organisasi / institusi. Menurut Siagian (2002) menyatakan masa kerja merupakan jangka waktu yang dibutuhkan seseorang dalam bekerja sejak mulai masuk lapangan pekerjaan hingga sekarang. Kurniadi (2013) menyatakan bahwa terdapat hubungan yang positif antara masa kerja dan komitmen organisasi. Semakin lama masa kerja seseorang, maka pengetahuan, keterampilan seseorang akan meningkat. Menurut peneliti, pengetahuan dapat diperoleh dari pengalaman. Maka semakin lama perawat berada pada suatu institusi / unit dapat memberikan pengalaman dan menambah pengetahuan dan keterampila perawat dalam tugasnya.

d. Pelatihan

Hasil penelitian ini menunjukkan bahwa sebagaian besar $(79,8 \%)$ perawat pelaksana belum mendapatkan pelatihan penyegaran tentang manajemen nyeri nonfarmakologis. Hasil ini sesuai dengan penelitian Zhang (2008) bahwa lebih dari separuh perawat $(56 \%)$ belum mendapatkan program pelatihan manajemen nyeri. Hasil ini juga didukung oleh penelitian Juwita (2014) menyatakan bahwa sebagian besar $(84,6 \%)$ perawat pelaksana tidak pernah mengikuti pelatihan manajemen nyeri.

Pelatihan merupakan pendidikan informal yang bertujuan untuk meningkatkan pengetahuan dan keterampilan perawat dalam melaksanakan asuhan keperawatan. Pelatihan dan pengembangan staf diartikan sebagai usaha terencana organisasi untuk meningkatkan pengetahuan, keterampilan dan kemampuan pegawai (Hariandja, 2002). Menurut peneliti, pelatihan merupakan aspek penting untuk dilaksanakan oleh organisasi untuk meningkatkan kinerja perawat dalam pemberian asuhan keperawatan.

\section{Pengetahuan}

Hasil penelitian menunjukkan lebih dari separuh responden $(68,5 \%)$ menunjukkan pengetahuan yang baik tentang manajemen nyeri nonfarmakologis. Hasil penelitian ini sesuai dengan penelitian Al-shaer et al (2011) menjelaskan bahwa pengetahuan dan sikap perawat tentang majemen nyeri sudah cukup baik $(61,2 \%)$. Pada penelitian Alnems (2012) juga menyatakan bahwa separuh 
perawat $(50 \%)$ memiliki pengetahuan yang baik terhadap manajemen nyeri. Pernyataan diatas juga diperkuat oleh Penelitian Ampomah (2012), separuh responden yang memiliki pengetahuan yang tinggi tentang manajemen nyeri $(50,7 \%)$.

Keraf dan Dua (2001) menyatakan pengetahuan adalah keseluruhan pemikiran, gagasan, ide, konsep dan pemahaman yang dimiliki manusia tentang dunia dan segala isinya termasuk manusia dan kehidupannya. Potter \& Perry (2005) mengemukakan bahwa yang mempengaruhi tingkat pengetahuan adalah tahap perkembangan, latar belakang pendidikan dan pengalaman masa lalu.

Berdasarkan hasil analisis kuesioner memperlihatkan bahwa lebih dari separuh $(68,5 \%)$ perawat pelaksana memiliki pengetahuan yang kurang baik tentang waktu dilakukannya skrinnig nyeri. Selain itu lebih dari separuh $(69,7 \%)$ perawat pelaksana belum mengetahui tentang instrument yang digunakan untuk mengkaji skala nyeri pasien dan lebih dari separuh (73\%) perawat pelaksana tidak memahami tentang poin $\mathrm{P}$ (pencetus) \& $\mathrm{R}$ (Regio/penyebaran) dalam pengkajian PQRST nyeri.

Intervensi nonfarmakologis dalam penelitian ini berupa relaksasi, distraksi dan masase. Berdasarkan hasil analisis peneliti lebih dari separuh $(53,9 \%)$ perawat pelaksana telah memahami tentang relaksasi nafas dalam. Namun sebagian besar $(77,5 \%)$ perawat pelaksana tidak mengetahui tentang distraksi dan lebih dari separuh $(67,4 \%)$ perawat pelaksana tidak memahami tentang terapi masase untuk pasien nyeri. Maka peneliti mengambil kesimpulan bahwa perawat pelaksana masih belum memahami manajemen nyeri secara menyeluruh, khususnya tentang asesmen nyeri dan manajemen nyeri nonfarmakologis distraksi dan masase.

\section{Sikap}

Hasil penelitian menunjukkan bahwa lebih dari separuh perawat $(58,4 \%)$ memiliki sikap yang negatif terhadap manajemen nyeri non farmakologis pasien. Hasil ini berbeda dengan penelitian Alshaer et al (2011) yang menyatakan bahwa pengetahuan dan sikap perawat tentang majemen nyeri sudah cukup baik $(61,2 \%)$. Sikap adalah respon seseorang yang masih tertutup terhadap suatu stimulus atau objek. Manifestasi dari sikap tidak dapat langsung dilihat namun hanya bisa ditafsirkan terlebih dahulu dari perilaku yang tertutup.Menurut peneliti perawat belum memahami bahwa manajemen nyeri nonfarmakologis diberikan secara tunggal kepada pasien dengan skala nyeri ringan. Sedangkan untuk skala nyeri sedang hingga berat manajemen nyeri nonfarmakologis diberikan secara kombinasi dengan manajemen nyeri farmakologis.

\section{Motivasi}

Hasil penelitian menunjukkan bahwa lebih dari separuh $(62,9 \%)$ perawat memiliki motivasi yang rendah terhadap manajemen nyeri nonfarmakologis. Hal ini sesuai dengan hasil penelitian Zuhriana (2012) menyatakan bahwa sebagian besar $(79,4 \%)$ perawat pelaksana memiliki motivasi kerja tinggi. Menurut pendapat Keith Davis dalam Mangkunegara (2005), bahwa faktor yang mempengaruhi pencapaian kinerja adalah faktor kemampuan (ability) dan faktor motivasi (motivation). Menurut Ilyas (2012) motivasi dapat diartikan sebagai kondisi internal, kejiwaan dan mental manusia seperti aneka keinginan, harapan, kebutuhan, dorongan dan kesukaan yang mendorong individu untuk berperilaku kerja untuk mencapai kepuasan atau mengurangi ketidakseimbangan.

Berdasarkan analisis kuesioner, masih ada perawat yang memiliki motivasi rendah dalam mengurangi rasa nyeri pasien, dan motivasi yang rendah dalam mengambil inisiatif dalam melaksanakan manajemen nyeri nonfarmakologis. Menurut asumsi peneliti hal tersebut bisa terjadi karena tingginya beban kerja di ruangan dan tingginya stress kerja perawat di Irna Non Bedah. Berdasarkan hasil wawancara kepada 3 orang perawat pelaksana menyatakan bahwa beban kerja perawat di ruangan cukup tinggi karena perbandingan antara perawat dan pasien tidak sesuai.

\section{Faktor Pendorong Pelaksanaan Manajemen Nyeri Nonfarmakologis Oleh Perawat Pelaksana Di Irna Non Bedah RSUP Dr M Djamil Padang Tahun 2015 Supervisi}

Hasil penelitian ini menunjukkan lebih dari separuh perawat pelaksana $(51,7 \%)$ memiliki persepsi kurang baik terhadap supervisi yang dilakukan oleh kepala ruangan tentang manajemen nyeri nonfarmakologis. Hasil ini berbeda dengan penelitian yang dilakukan oleh Juwita (2014) didapatkan bahwa lebih dari separuh $(53,8 \%)$ perawat memiliki persepsi yang baik terhadap supervisi yang dilakukan oleh kepala ruangan terkait penatalaksanaan nyeri pasien. Supervisi dalam keperawatan dilakukan untuk memastikan kegiatan dilaksanakan sesuai dengan visi, misi, dan tujuan organisasi serta sesuai dengan standar yang telah ditetapkan (Keliat, dkk, 2006).

Berdasarkan analisis kuesioner supervisi dapat dilihat bahwa lebih dari separuh $(50,6 \%)$ perawat pelaksana menyatakan kepala ruangan belum memotivasi perawat dalam melaksanakan manajemen nyeri nonfarmakologis. Lebih dari separuh $(59,6 \%)$ perawat memiliki persepsi bahwa kepala ruangan kurang memberikan arahan tentang manajemen nyeri nonfarmakologis. Selain itu kurang dari separuh $(34,8 \%)$ perawat pelaksana merasa kesulitan menghubungi kepala 
ruangan saat menemukan masalah tentang manajemen nyeri.

Faktor Predisposisi Yang Berhubungan Dengan Pelaksanaan Manajemen Nyeri Nonfarmakologis Oleh Perawat Pelaksana Di Irna Non Bedah RSUP Dr M Djamil Padang

1. Hubungan Karakteristik Perawat Dengan Pelaksanaan Manajemen Nyeri Nonfarmakologis

a. Hubungan usia dengan Pelaksanaan Manajemen Nyeri Nonfarmakologis

Hasil penelitian menunjukkan bahwa lebih dari separuh $(59,8 \%)$ perawat usia dewasa awal baik dalam melaksanakan manajemen nyeri nonfarmakologis. Hasil ini sejalan dengan penelitian Nasution (2009) menunjukkan bahwa $75,8 \%$ perawat dengan usia $<39$ tahun memiliki kinerja kurang baik. Berdasarkan uji statistik tidak terdapat hubungan yang bermakna antara usia dengan pelaksanaan manajemen nyeri nonfarmakologis oleh perawat pelaksana dengan nilai P 1,000 .

Hasil penelitian diatas sesuai dengan penelitian Ayla (2013) yang menyatakan bahwa tidak ada hubungan yang signifikan antara usia perawat dengan pengetahuan dan praktek manajemen nyeri. Menurut peneliti, hal ini terjadi karena sebaran usia responden dalam penelitian ini tidak bervariasi.

Menurut analisa peneiliti peningkatan usia dapat mencerminkan kematangan perawat dalam berfikir dan bertindak, namun produktivitas / kinerja perawat yang mengalami peningkatan usia akan mengalami penurunan. Hal ini dapat disebabkan karena penurunan fungsi fisiologis tubuh perawat yang terjadi seiring dengan bertambahnya usia.

b. Hubungan Pendidikan dengan Pelaksanaan Manajemen Nyeri Nonfarmakologis

Berdasarkan uji statistik menunjukkan bahwa tidak terdapat hubungan yang bermakna antara tingkat pendidikan dengan pelaksanaan manajemen nyeri nonfarmakologis oleh perawat pelaksana $(P$ value $=1,000)$. Hal ini sesuai dengan penelitian yang dilakukan oleh Alshaer (2011) bahwa tidak terdapat hubungan yang signifikan antara tingkat pendidikan perawat dengan manajemen nyeri. Hasil ini juga sejalan dengan hasil penelitian Yanti \& Warsito (2013) yang menyatakan tidak ada hubungan yang bermakna antara pendidikan dengan kinerja perawat pelaksana. Siagian (2002) menjelaskan bahwa pendidikan formal menyangkut kemampuan intelektual dan kemampuan individu dalam menyelesaikan tugasnya. Semakin tinggi tingkat pendidikan seseorang maka semakin besar keinginan untuk memanfaatkan pengetahuan dan keterampilan (Kurniadi, 2013).

Menurut Kusnanto (2004) pada tingkatan pendidikan Diploma III keperawatan, perawat pelaksana masih banyak membutuhkan arahan dan bimbingan dalam menyelesaikan tugas yang mereka lakukan. Tidak adanya hubungan pendidikan dengan kinerja perawat dapat terjadi karena masa kerja perawat yang sudah lebih dari 5 tahun, sehingga ilmu yang didapatkan saat pendidikan sudah terlupakan jika tidak diaplikasikan di lapangan. Karena perawat pelaksana di Irna non bedah sebagian besar adalah diploma III keperawatan, maka masih perlu diberikan bimbingan dan arahan dalam melaksanakan intervensi manajemen nyeri.

c. Hubungan Masa Kerja dengan Pelaksanaan Manajemen Nyeri Nonfarmakologis

Berdasarkan uji statistik menunjukkan tidak terdapat hubungan yang bermakna antara masa kerja perawat dengan pelaksanaan manajemen nyeri nonfarmakologis dengan $\mathrm{P}$ value 0,585 . Hasil ini bertolak belakang dengan penelitian AlShaer yang menyatakan bahwa ada hubungan yang signifikan antara masa kerja dengan pelaksanaan manajemen nyeri $(\mathrm{p}$ value $=0,012)$. Siagian (2002) menjelaskan bahwa seseorang yang sudah lama bekerja pada satu organisasi tidak identik dengan produktivitas yang tinggi. Masa kerja yang lama menunjukkan pengalaman yang lebih dari seseorang dibandingkan rekan kerja lainnya.

Menurut Kurniadi (2013) menyatakan bahwa masa kerja yang lama cenderung membuat perawat merasa lebih betah dalam suatu pekerjaan, berpengalaman, yang diakibatkan oleh adaptasi terhadap lingkungan, sehingga seseorang akan merasa nyaman dengan pekerjaannya. Namun hasil penelitian ini bertentangan dengan teori Kurniadi dan Wursanto, dapat dilihat bahwa lebih dari separuh perawat yang memiliki masa kerja lebih dari lima tahun, baik dalam melaksanakan manajemen nyeri. Maka dapat disimpulkan bahwa peningkatan masa kerja dapat menggambarkan pengalaman seseorang, namun tidak dapat dijadikan tolok ukur produktivitas seseorang.

d. Hubungan Pelatihan dengan Pelaksanaan Manajemen Nyeri Nonfarmakologis

Hasil penelitian menunjukkan sebagian besar perawat pelaksana $(83,3 \%)$ yang telah mendapatkan pelatihan manajemen nyeri dapat melakukan pelaksanaan manajemen nyeri dengan baik. Berdasarkan uji statistik terdapat hubungan yang bermakna antara pelatihan dengan pelaksanaan manajemen nyeri. Pendidikan dan 
pelatihan merupakan bagian dari investasi sumber daya manusia (human investment). Semakin lama waktu yang digunakan seseorang untuk pendidikan dan pelatihan, semakin tinggi kemampuan dan kompetensinya melakukan pekerjaan, maka semakin tinggi kinerjanya (Simanjuntak, 2005). Pelatihan manajemen nyeri merupakan investasi rumah sakit bagi sumberdaya manusia perawat untuk terus dapat meningkatkan kemampuannya dalam manajemen nyeri.

Abdalrahim (2011) mengemukakan bahwa pelatihan diperlukan untuk menambah pengetahuan dan memperbaiki sikap perawat dalam pelaksanaan manajemen nyeri. Sebab menurut Notoatmodjo (2007) menyatakan bahwa prilaku yang didasari oleh pengetahuan, kesadaran dan sikap yang positif akan bersifar langgeng (Lost Lasting). Pelatihan manajemen nyeri diharapkan dapat meningkatkan pengetahuan dan sikap perawat, sehingga pelaksanaan manajemen nyeri dapat lebih optimal. Hal ini didukung oleh pernyataan Zhang et al (2008) menyatakan bahwa pelaksanaan program pelatihan manajemen nyeri terutama untuk perawat sebagai pemberi pelayanan lini pertama sangat dibutuhkan. Sebab manajemen nyeri merupakan asuhan keperawatan yang memiliki dampak secara langsung kepada pasien.

2. Hubungan pengetahuan dengan pelaksanaan manajemen nyeri nonfarmakologis

Hasil penelitian menunjukkan lebih dari separuh $(50,8 \%)$ perawat pelaksana yang memiliki pengetahuan yang baik, maka dapat melaksanakan manajemen nyeri nonfarmakologis dengan baik dibandingkan dengan perawat pelaksana yang memiliki pengetahuan kurang. Berdasarkan uji statistik menunujukkan bahwa terdapat hubungan yang bermakna antara faktor pengetahuan dengan pelaksanaan manajemen nyeri nonfarmakologis. Hasil penelitian ini sesuai dengan penelitian Astuti (2012) bahwa terdapat hubungan yang signifikan antara pengetahuan perawat dengan pelaksanaan manajemen nyeri nonfarmakologis pada pasien pasca operasi bedah mayor. Hasil ini juga diperkuat oleh hasil penelitian Jho et al (2014) menyatakan bahwa pengetahuan perawat sangat berpengaruh terhadap pelaksanaan manajemen nyeri. Faktor pengetahuan mempunyai pengaruh sebagai dorongan awal dalam berperilaku. Semakin tinggi tingkat pengetahuan seseorang maka semakin baik perilaku seseorang. Schechter, Berde, \& Yaster (2003 dalam Stanley 2013) menyatakan bahwa pengetahuan perawat sangat mempengaruhi perilaku perawat dalam memberikan manajemen nyeri yang adekuat.
Pengetahuan dan perilaku erat sekali hubungannya, perawat dituntut harus mempunyai pengetahuan dalam melaksanakan praktek asuhan keperawatan pasien. Dalam jenjang pendidikan keperawatan, perawat sudah dikenalkan dengan manajemen nyeri nonfarmakologis, sehingga perawat harusnya sudah memiliki pengetahuan yang baik tentang manajemen nyeri. Selain pernah memperoleh pengetahuan tentang manajemen nyeri, perawat juga perlu untuk mempertahankan pengetahuan tersebut. Mempertahankan pengetahuan dapat dilakukan dengan mengingat kembali (recall) (Notoatmodjo, 2007). Oleh sebab itu perawat harus mendapatkan penyegaran informasi tentang manajemen nyeri nonfarmakologis.

Hasil penelitian ini menunjukkan bahwa pengetahuan perawat tentang manajemen nyeri nonfarmakologis sudah baik. Peneliti berasumsi mayoritas pengetahuan perawat sudah baik disebabkan perawat sudah dibekali dengan adanya buku akreditasi individu yang salah satunya memuat tentang pengkajian nyeri pasien. Namun pengetahuan perawat yang sudah baik tidak selalu mencerminkan bahwa perawat tersebut baik dalam melakukan manajemen nyeri. Hal ini dapat dilihat pada hasil penelitian, dimana kurang dari separuh perawat yang pengetahuannya baik, baik dalam pelaksanaan manajemen nyeri. Menurut peneliti, ini terjadi karena perawat hanya mengetahui teori manajemen nyeri, namun belum memahami poin-poin dalam pengkajian dan intervensi nyeri.

3. Hubungan sikap dengan pelaksanaan manajemen nyeri nonfarmakologis

Hasil penelitian menunjukkan sebagian perawat pelaksana $(75 \%)$ yang memiliki sikap negatif, baik dalam melaksanakan manajemen nyeri non farmakologis. Berdasarkan uji statistik menunjukkan bahwa terdapat hubungan yang bermakna antara sikap perawat dengan pelaksanaan manajemen nyeri nonfarmakologis oleh perawat dengan Pvalue $=0,000$. Hal ini sesuai dengan penelitian yang dilakukan Al Shaer et al (2011) menyatakan bahwa sikap perawat memiliki pengaruh yang kuat terhadap keberhasilan pelaksnaan manajemen nyeri.

Sikap merupakan konsep yang sangat penting dalam komponen sosio-psikologis, karena merupakan kecenderungan bertindak dan berpersepsi. Sikap adalah bentuk respons tertutup seseorang terhadap stimulus atau objek tertentu, yang sudah melibatkan faktor pendapat dan emosi yang bersangkutan seperti: senang/tidak senang, setuju/tidak setuju, baik/tidak baik (Notoatmodjo, 2007). 
Fitria Fajriani et al., Analisis Faktor yang Berhubungan dengan Pelaksanaan Manajemen Nyeri Non Farmakologis Oleh Perawat Pelaksana di Irna Non Bedah RSUP Dr M Djamil Padang Tahun 2015

4. Hubungan motivasi dengan pelaksanaan manajemen nyeri non farmakologis

Hasil penelitian menunjukkan lebih dari separuh $(73,2 \%)$ perawat pelaksana yang memiliki motivasi rendah, baik dalam melaksanakan manajemen nyeri nonfarmakologis. Berdasarkan uji statistik terdapat hubungan yang bermakna antara motivasi dengan pelaksanaan manajemen nyeri perawat pelaksana di Irna non bedah RSUP Dr M Djamil Padang dengan $P$ value 0,001. Hasil penelitian ini sesuai dengan penelitian Makta, Noor \& Kapalawi (2013) menunjukkan bahwa terdapat pengaruh secara signifikan motivasi terhadap kinerja perawat pelaksana di RS Stella Maris. Sementara itu hasil ini sesuai dengan penelitian Zuhriana (2012) bahwa terdapat hubungan bermakna antara motivasi dengan kinerja perawat dengan nilai $\mathrm{p}=0,019$.

Menurut Kurniadi (2013) menyatakan motivasi merupakan karakteristik psikologi manusia yang memberi kontribusi pada tingkat komitmen seseorang. Sedangkan menurut Triwibowo (2013) motivasi diartikan sebagai kekuatan, dorongan, kebutuhan, semangat, tekanan, atau mekanisme psikologis yang mendorong seseorang atau sekelompok orang untuk mencapai prestasi tertentu sesuai dengan apa yang dikehendakinya. Menurut Siagian (2002), motivasi merupakan akibat dari interaksi seseorang dengan situasi tertentu yang dihadapinya. Karena itulah terdapat perbedaan dalam kekuatan motivasi yang ditunjukkan oleh seseorang dalam menghadapi situasi tertentu dibandingkan dengan orang-orang lain yang menghadapi situasi yang sama.

Menurut peneliti semakin tinggi motivasi perawat, maka perawat tersebut akan semakin baik dalam melaksanakan manajemen nyeri nonfarmakologis. Motivasi yang dimaksud dalam penelitian ini adalah motivasi internal perawat dalam melaksanakan manajemen nyeri nonfarmakologis. motivasi merupakan hal yang penting bagi individu sebagai penggerak dalam menjalankan kegiatan dan tugas secara bertanggung jawab untuk meraih prestasi. Fenomena masih adanya perawat yang memiliki motivasi yang rendah dalam pelaksanaan manajemen nyeri dapat disebabkan oleh faktor motivasi eksternal seperti ketidakjelasan jenjang karir dan reward yang diberikan kepada perawat yang telah melaksanakan manajemen nyeri dengan baik. Selain itu belum adanya SPO tentang manajemen nyeri nonfarmakologis juga dapat menyebabkan motivasi internal perawat menjadi rendah. Oleh sebab itu rumah sakit harus membuat program yang dapat meningkatkan motivasi internal perawat dengan memberikan stimulus dari eksternal perawat.
Faktor Pendorong Yang Berhubungan Dengan Pelaksanaan Manajemen Nyeri Nonfarmakologis Oleh Perawat Pelaksana Di Irna Non Bedah RSUP Dr M Djamil Padang

Hubungan Supervisi Kepala Ruangan Terhadap Manajemen Nyeri Non Farmakologis

Berdasarkan uji statistik didapatkan bahwa tidak terdapat hubungan yang bermakna antara supervisi kepala ruangan dengan pelaksanaan manajemen nyeri non farmakologis. Hasil ini sejalan dengan penelitian yang dilakukan Pancaningrum (2011) didapatkan bahwa tidak ada hubungan yang bermakna antara supervisi kepala ruangan dengan kinerja perawat pelaksana. Hasil penelitian ini juga berbeda dengan penelitian Juwita (2014) dimana terdapat hubungan yang signifikan antara supervisi kepala ruangan dengan pengelolan nyeri pasien.

Hal ini terjadi karena supervisi yang terjadi di ruangan lebih bersifat kepada pengawasan saja, sedangkan dalam pelaksanaan manajemen nyeri perawat pelaksana sangat membutuhkan bimbingan dan arahan. Keadaan tersebut didukung oleh hasil kuesioner yang mana lebih dari separuh perawat $(59,6 \%)$ menyatakan kepala ruangan kurang baik dalam memberikan arahan tentang manajemen nyeri. Selain itu $50,6 \%$ perawat pelaksana juga mengatakan bahwa Kepala ruangan kurang memotivasi perawat untuk melaksanakan manajemen nyeri.

Keadaan ini bertolak belakang dengan pernyataan Swansburg (2000) yang menyatakan bahwa aktivitas pada supervisi adalah mengajarkan, membimbing, mengobservasi, dan mengevaluasi secara terus menerus dengan adil, sabar, serta bijaksana sehingga setiap perawat pelaksana dapat memberikan asuhan keperawatan dengan baik, terampil, aman, cepat, tepat secara menyeluruh sesuai dengan standar. Supervisi bertujuan untuk mengorientasikan, melatih kerja, memimpin, memberikan arahan, dan mengembangkan kemampuan perawat pelaksana. Menurut Sitorus (2011) supervisi merupakan proses formal dari belajar dan bimbingan profesional yang memungkinkan perawat praktisi untuk mengembangkan pengetahuan, kompetensi dan menerima tanggung jawab dalam praktiknya dan meningkatkan perlindungan terhadap pasien dan pelayanan keperawatan yang aman dalam situasi yang kompleks.

Pada penelitian ini yang dinilai adalah persepsi Perawat Pelaksana tentang supervisi Kepala Ruangan. Hubungan interpersonal dan komunikasi perawat pelaksana dengan kepala ruangan akan mempengaruhi persepsi perawat pelaksana tentang supervisi Kepala ruangan.

Menurut peneliti kegiatan supervisi yang paling berperan dalam meningkatkan keterampilan perawat dalam melaksanakan manajemen nyeri nonfarmakologis adalah supervisi klinik. Bann dan Holland menyatakan 
Fitria Fajriani et al., Analisis Faktor yang Berhubungan dengan Pelaksanaan Manajemen Nyeri Non Farmakologis Oleh Perawat Pelaksana di Irna Non Bedah RSUP Dr M Djamil Padang Tahun 2015

bahwa supervisi klinik berguna untuk memfasilitasi perawat praktisi pada praktek klinik secara teratur untuk mencapai, menopang dan mengembangkan secara kreatif praktek yang berkualitas tinggi melalui fokus dukungan dan pengembangan.

Winstanley dan White (2008) menyatakan bahwa kualitas supervisi klinik tergantung pada faktor eksternal hubungan Supervisor dan Supervise yaitu organisasi dan budaya manajemen. Supervisi bertujuan untuk meningkatkan kualitas pelayanan keperawatan. Supervisi merupakan bagian dari fungsi pengarahan yang dilakukan oleh Supervisor untuk melakukan monitoring kegiatan pelaksanaan keperawatan. Persepsi perawat pelaksana tentang supervisi juga dipengaruhi oleh pengalaman perawat di ruangan tentang supervisi Kepala ruangan. Semakin baik pengalaman dan hubungan interpersonal Perawat pelaksana dengan Kepala ruangan maka persepsi perawat tentang supervisi akan semakin baik.

Faktor yang paling dominan berhubungan dengan pelaksanaan manajemen nyeri nonfarmakologis di Irna Non Bedah RSUP Dr M Djamil Padang

Hasil penelitian multivariat dengan analisis regresi logistik menunjukkan bahwa variabel yang paling dominan berhubungan dengan pelaksanaan manajemen nyeri nonfarmakologis adalah pelatihan manajemen nyeri ( $\mathrm{p}$ value $=0,005)$.. Hasil penelitian ini didukung oleh penelitian Swain (2008) yang menyatakan bahwa pelatihan memiliki peranan dalam meningkatkan pengetahuan dan sikap perawat tentang manajemen nyeri sehingga terjadi peningkatan terhadap pelaksanaan manajemen nyeri.

Menurut peneliti pelatihan merupakan program yang bertujuan untuk meningkatkan pengetahuan, merubah sikap ke arah yang positif dan meningkatkan keterampilan. Pendapat tersebut didukung oleh pernyataan Marquis \& Huston (2010) mengartikan pelatihan sebagai metode yang terorganisir untuk memastikan bahwa individu memiliki pengetahuan dan keterampilan tertentu sehingga dapat meningkatkan kemampuan afektif, kognitif dan psikomotor yang akhirnya akan meningkatkan produktivitas.

Menurut Mc.Cutchon et al (2006 dalam Nursalam 2012) menyatakan bahwa SDM Keperawatan memiliki kebutuhan yang besar untuk mendapatkan pendidikan dan pelatihan berkelanjutan dlam berbagai jenjang untuk mendukung penerapan dalam melakukan tindakan. Beazley et al (2002) mengemukakan bahwa pengelolaan pengetahuan secara berkelanjutan merupakan suatu bentuk transfer pengetahuan untuk mendukung staf memperoleh kesuksesan atas pelayanan yang mereka berikan. Maka dapat disimpulkan, perawat yang mendapatkan pelatihan akan memiliki kinerja yang baik jika sudah memiliki pengetahuan yang cukup dan mengaplikasi pengetahuan tersebut dalam perilaku kerja dan kinerjanya.

\section{SIMPULAN}

Mayoritas perawat pelaksana di Irna Non Bedah berada pada usia dewasa awal, memiliki latar belakang pendidikan Diploma III Keperawatan dengan masa kerja lebih dari 5 tahun, serta mayoritas perawat belum pernah mendapatkan pelatihana manajemen nyeri nonfarmakologis.

Lebih dari separuh perawat pelaksana di Irna Non Bedah tidak kompeten dalam melaksanakan manajemen nyeri nonfarmakologis.

Lebih dari separuh perawat pelaksana di Irna Non Bedah memiliki pengetahuan yang baik, sikap yang negatif, motivasi yang rendah dan persepsi yang kurang baik terhadap supervisi kepala ruangan.

Ada hubungan yang bermakna antara faktor predisposisi (pelatihan, pengetahuan, sikap dan motivasi) dengan pelaksanaan manajemen nyeri nonfarmakologis oleh perawat pelaksana di Irna Non Bedah RSUP M Djamil Padang. Tidak ada hubungan yang bermakna antara faktor pendorong (supervisi) dengan pelaksanaan manajemen nyeri nonfarmakologis oleh perawat pelaksana di Irna Non Bedah RSUP M Djamil Padang. Pelatihan adalah faktor yang paling berkontribusi terhadap pelaksanaan manajemen nyeri nonfarmakologis oleh perawat pelaksana di Irna Non Bedah RSUP M DJamil Padang.

\section{DAFTAR PUSTAKA}

Abdalrahim, M.S Majali, S.A, Stomberg, M.W, \& Bergbom,I (2011) the effect of postoperative pain management pain management program on improving nurses knowledge and attitudes toward pain. Nurse Education in Practice. Diakses tanggal 24 Maret 2015

Alshaer D, HillP, D \& Anderson, M.A (2011) Nurses Knowledge and attitudes regarding pain assessment and intervention. Research for Pratice. Diakses tanggal 15 Januari 2015

Ampomah, D K. (2012).Knowledge, Attitudes and Beliefs About Pain Management: A Comparative Study Of United States-Born and West African born nurses worked at United States. Proquest Dissertations and Theses. Diakses tanggal 14 Februari 2015

Ayla, Yava (2013). Knowledge and Attitudes of Nurses about Pain Management in Turkey. International Journal of Caring Sciences. http://proquest.com/ diakses tanggal 10 September 2015

Beazley, H, et.al. (2002). Continuity Management: Preserving Corporate Knowledge and Productivity When Employees Leave.New York: Wiley. 
Fitria Fajriani et al., Analisis Faktor yang Berhubungan dengan Pelaksanaan Manajemen Nyeri Non Farmakologis Oleh Perawat Pelaksana di Irna Non Bedah RSUP Dr M Djamil Padang Tahun 2015

Bobak, Lowdermilk. Jensen. (2004). Buku Ajar Keperawatan Maternitas. Jakarta: EGC

Buyukyilmaz. (2014). Non- Pharmacological Intervention in Orthopedic Pain: A Systematic Review. Turki : International Journal of Caring Sciences.diakses tanggal 24 Januari 2015

Casey, Georgina. (2011). Pain- The fifth vital sign. New Zealand ; Kai tiaki nursing journal diakses tanggal 20 januari 2015.

Chuandy, Indra \& Sugeng (2015). Konsep Pain Free Hospital, Surakarta: Cermin Dunia Kedokteran

El-Rahman, M.A. et al (2013). Knowledges and Attitude Towards Pain Management, A Comparassion between Oncology and Non-Oncology Nurses in Jordan. International Journal of Advanced Nursing Studies.

Hariandja, Marihot. (2002). Manajemen Sumber Daya Manusia. Jakarta: Grasindo

Ilyas (2012) Kinerja Teori penilaian dan penelitian. Depok: Pusat Kajian Ekonomi Kesehatan FKMUI

Jho et al (2014) Knowledge, Practices, and Perceived Barriers Regarding Cancer Pain Management among Physicians and Nurses in Korea: A Nationwide Multicenter Survey. Medical Professional's Knowledge and Practice for Cancer Pain in Korea

Juwita, Lisavina (2014) Hubungan model supervise kepala ruangan dengan kemampuan perawat pelaksana dalam pengelolaan nyeri di ruang rawat inap RSUD Dr M Zein Painan tahun 2014. Tesis. FKep Unand

Keraf.\& Dua (2001). Ilmu Pengetahuan. Jakarta : Kanisius

Kurniadi, Anwar .(2013). Manajemen keperawatan dan prospektifnya teori konsep dan aplikasi. Jakarta ; FKUI

Kusyati, E., \& Astuti, L. P. (2012). Efektivitas Teknik Relaksasi Nafas Dalam Terhadap Tingkat Nyeri Persalinan Kala I Di Wilayah Kerja Puskesmas Tlogosari Wetan Semarang Tahun 2012. Jurnal Kebidanan, 4(2).

Makta, L., Noor, H. N. B., Sc, M., Kapalawi, I., \& Mars, M. S. P. H. (2013). Pengaruh Motivasi Kerja Dengan Kinerja Perawat Pelaksana Di Unit Rawat Inap Rs. Stella Maris Makassar.

Morone, Natalia E.\& Weiner (2013). Pain as the fifth vital sign: exposing the vital need for pain educaton. Clinical therapeutics journal. Diakses tanggal 20 Januari 2015.

Marquis B,L \& Huston C.J (2010). Management and Leadership in nursing health care.New York : Spinger Pub

Nasution, Ade Ira Zahriany. (2009) pengaruh karakteristik individu dan psikologis terhadap kinerja perawat dalam kelengkapan rekam medis di ruang rawat inap rumah sakit umum $d r$. Pirngadi medan. USU : Tidak dipublikasikan.

Notoatmodjo, S. (2007). Kesehatan Masyarakat ilmu dan seni. Jakarta : PT Rineka Cipta

Notoatmodjo, S. (2012). Promosi kesehatan dan perilaku kesehatan. Jakarta : PT Rineka Cipta

Nugroho, K (2004). Analisis faktor-faktor yang berhubungan dengan kinerja perawat pegawai daerah di Puskesmas Kabupaten Kudus.Tesis FKM-UNDIP. Diakses tanggal 2 Oktober 2015 dari http://www.eprint.undip.ac.id

Nursalam. (2012). Manajemen Keperawatan: Aplikasi dalam Praktek Keperawatan Profesional, Edisi 3: Salemba Medika

Pancaningrum, D. (2011). Faktor - Faktor yang Mempengaruhi Kinerja Perawat Pelaksana di Ruang Rawat Inap Dalam Pencegahan Infeksi Nosokomial di Rumah Sakit Haji Jakarta Tahun 2011. Tesis. Tidak dipublikasikan. Jakarta: Fakultas Ilmu Keperawatan Universitas Indonesia.

Potter \&Perry . (2005). Fundamental Keperawatan Volume 2. Jakarta : Buku Kedokteran EGC

Siagian. (2002). Manajemen abad 21. Jakarta: Bumi Aksara

Swain (2008). The effect of education about pain management on The knowledge and attitudes of nurses.

Swansburg, C, R. (2000). Pengantar manajemen keperawatan untuk perawat klinis. Jakarta: EGC Kedokteran.

Sitorus, Ratna. (2011). Manajemen Keperawatan di Ruang Rawat Inap. Jakarta: Sagung Seto.

Smeltzer \& Bare (2002) Buku Ajar Keperawatan Medikal Bedah Brunner dan Suddarth (Ed.8, Vol. 1,2), Alih bahasa oleh Agung Waluy (dkk), EGC, Jakarta.

Triwibowo, Cecep. (2013). Manajemen pelayanan keperawatan di rumah sakit. Jakarta : TIM

White, L. (2001). Foundations of nursing: caring for the whole person. New York: Delmar Thomson Learning.

Winstanley, J., \& White, E. (2008). Clinical supervision: Models, measures and best practice. Nurse Researcher, 10(4), 7-38. http:// search.proquest.com/ docview/ 200775851? accountid $=17242$

Zhang,C.H ,Hsu, L,Zou, B.R,Li,J.F,Wang, H.Y \& Huang,J (2008) Effect of a pain education program on nurse's pain knowledge, attitude, and pain assessment practice in China. Journal of Pain and Symptom Management.

Zuhriana (2012) Faktor Yang Berhubungan Dengan Kinerja Perawat Di Unit Rawat Inap Rumah Sakit Umum Daerah (Rsud) Bula Kabupaten Seram Bagian Timur. Tesis FIK UI.Tidak Dipublikasikan 